\title{
Фенотипирование картофеля (Solanum tuberosum L.) по биохимическим параметрам крахмала
}

Т.В. Эрст, Л.М. Гвоздева, В.К. Хлесткин*

ФИЦ Институт цитологии и генетики СО РАН, Новосибирск, Россия

*e-mail: khlestkin@bionet.nsc.ru

В ходе развития мировой экономики и производства растения становятся источниками не только пищи, но и ряда новых материалов - композитов, волокон, углеродных материалов, новых «строительных блоков» для химической промышленности, лекарственных средств и микро- и наноустройств для их доставки. Соответствующим отраслям важно обеспечить себя надежными источниками сырья со строго определенными свойствами. Поэтому наряду с агротехнологиями выращивания и методами переработки биомассы идет работа над тонкой настройкой генетических сетей значимых растений с целью оптимизировать их работу так, чтобы повысить эффективность использования вложенных энергетических и материальных ресурсов, а также обеспечить на выходе сырье с требуемыми заданными параметрами.

Картофель (Solanum tuberosum L.) является значимым источником качественного крахмала, доступного и экономичного сырья как для пищевой, так и для перерабатывающей промышленности. Нативный картофельный крахмал представляет собой овальные гранулы сложного строения. В состав гранулы крахмала входят два типа полимерных биомолекул - полисахариды амилоза и амилопектин в соотношении примерно 25:75. Оба полисахарида являются полимерами глюкозы, линейным (амилоза) и разветвленным (амилопектин). Такое устройство крахмала дает возможность предположить целый ряд его молекулярных параметров, влияющих на конечные, практически важные для промышленности свойства: выход крахмала, кристалличность гранул, морфологические признаки гранул, соотношение амилоза/амилопектин, молекулярные веса полисахаридов, разветвленность амилопектина, содержание фосфатных групп.

В ходе данной работы проведено фенотипирование 90 сортов картофеля по химическим свойствам крахмала и определены следующие его параметры:

- содержание фосфора (в виде фосфата);

- устойчивость к действию амилаз;

- содержание амилозы;

- $\quad$ морфологические характеристики гранул.

Методом главных компонент выявлены взаимные корреляции некоторых свойств крахмала и агрономических параметров растения. Анализ крахмала 2016 и 2017 гг. позволил установить наличие генетического вклада в морфологии крахмальных гранул. В настоящее время проводится работа по установлению ассоциаций «генотип - химический признак крахмала» на основе генотипирования на SNPчипе.

Благодарности: Работа выполнена при финансовой поддержке гранта РФФИ № 17-29-08006. 